\title{
MANAGEMENT AND ADMINISTRATION
}

DOI https://doi.org/10.51647/kelm.2021.3.2.23

\section{ZARZĄDZANIE PROJEKTAMI W STRUKTURZE MECHANIZMU ROZWOJU BRANŻ KREATYWNYCH: ASPEKT KULTUROZNAWCZY}

\author{
Khrystyna Pletsan \\ kandydat nauk z administracji publicznej, docent, \\ docent Naukowo-Dydaktycznego Instytutu \\ Kijowskiego Narodowego Uniwersytetu Kultury i Sztuki (Kijów, Ukraina) \\ ORCID ID: 0000-0002-8179-7896 \\ e-mail:k.pletsan@gmail.com
}

\begin{abstract}
Adnotacja. Na obecnym etapie zarządzanie projektami odgrywa ważną rolę w opracowywaniu i promowaniu produktu kulturalnego branż kreatywnych i ma znaczący wpływ na rozwój kulturowy społeczeństwa. Pełniąc rolę mechanizmu rozwoju i popularyzacji branży kreatywnej, zarzadzanie projektami stało się popularną forma konsumpcji kulturowej, odpowiednio wpływając na zasoby ludzkie i kształtując odpowiedni styl życia i postrzeganie świata przez człowieka.

W badaniu przeanalizowano historyczno-kulturowy aspekt wdrażania zarzadzania projektami w branżach kreatywnych Ukrainy. Wyróżniono i przeanalizowano badania przedmiotowe w środowisku kulturowo-kreatywnym. Zaproponowano i uzasadniono algorytm realizacji projektu kulturalnego. Na podstawie badań literatury teoretycznej i praktycznej podkreślono główne wskaźniki i kryteria powodzenia projektu w środowisku branż kreatywnych. Usystematyzowanie analizowanego materiału umożliwiło stworzenie i uzasadnienie mapy drogowej udanej realizacji projektu kulturalnego w środowisku branż kreatywnych Ukrainy. Udowodniono znaczenie wdrożenia zarządzania projektami jako możliwości tworzenia warunków twórczej aktywności i konkurencyjnej przestrzeni kulturalnej i twórczej.

Znaczenie badań nad działalnością projektową w środowisku branż kreatywnych, przez pryzmat aspektu historycznokulturowego zależy od uniwersalności i różnorodności, zapewniając popularyzacje i zachowanie dziedzictwa kulturowego narodu.

Słowa kluczowe: kultura, aspekt historyczno-kulturoznawczy, zarządzanie projektami, branże kreatywne, zarządzanie działaniami projektowymi w branżach kreatywnych, kultura projektowa, konkurencyjność.
\end{abstract}

\section{PROJECT MANAGEMENT IN THE STRUCTURE OF THE MECHANISM OF DEVELOPMENT OF CREATIVE INDUSTRIES: CULTUROLOGICAL ASPECT}

\author{
Khrystyna Pletsan \\ PhD in Public Administration, Associate Professor, \\ Associate Professor \\ Research Institute \\ of the Kyiv National University of Culture and Arts (Kyiv, Ukraine) \\ ORCID ID: 0000-0002-8179-7896 \\ e-mail:k.pletsan@gmail.com
}

\begin{abstract}
At the present stage, project management plays an important role in the development and promotion of the cultural product of creative industries and has a significant impact on the cultural development of society. The study analyzes the historical and cultural aspect of the implementation of project management in the creative industries of Ukraine. A roadmap for the successful implementation of a cultural project among the creative industries of Ukraine has been formed and substantiated. The theoretical aspect of the problems and possibilities of using project management in creative industries is described. The importance of project management implementation as an opportunity to create conditions for creative activity and competitive cultural and creative space is proved. The relevance of the study of project activities in the environment of creative industries, through the prism of the historical and cultural aspect is determined by the universality and cross-sectorality, ensures the promotion and preservation of cultural heritage of the nation.

Key words: culture, historical and cultural aspect, project management, creative industries, project management in creative industries, project culture of personality, competitiveness.
\end{abstract}




\title{
ПРОЄКТНИЙ МЕНЕДЖМЕНТ У СТРУКТУРІ МЕХАНІЗМУ РОЗВИТКУ КРЕАТИВНИХ ІНДУСТРІЙ: КУЛЬТУРОЛОГІЧНИЙ АСПЕКТ
}

\author{
Христина Плецан \\ дочент, кандидат наук з державного управління, \\ доиент \\ Навчально-наукового інституту \\ Київського національного університету культури імистецтв (Київ, Украӥна) \\ ORCID ID: 0000-0002-8179-7896 \\ e-mail:k.pletsan@gmail.com
}

\begin{abstract}
Анотація. На сучасному етапі проєктний менеджмент відіграє важливу роль у розробці та просуванні культурного продукту креативних індустрій і має значний вплив на культурний розвиток суспільства. Виконуючи роль механізму розвитку та популяризації креативних індустрій, проєктний менеджмент став популярною формою культурного споживання, впливаючи на людські ресурси та формуючи відповідний спосіб життя і світосприйняття людини.

У дослідженні проаналізовано історико-культурний аспект впровадження проєктного менеджменту у креативних індустріях України. Виокремлено та проаналізовано тематичні дослідження у культурно-креативному середовищі. Запропоновано й обгрунтовано алгоритм реалізації культурного проєкту. На основі дослідження теоретичної та практичної літератури виокремлено основні показники та критерії успішності реалізації проєкту в середовищі креативних індустрій. Систематизація проаналізованого матеріалу дала можливість сформувати й обгрунтувати дорожню карту успішної реалізації культурного проєкту в середовищі креативних індустрій України. Доведено важливість реалізації проєктного менеджменту як можливості створення умов для творчої активності та конкурентного культурно-креативного простору.

Актуальність дослідження проєктної діяльності у середовищі креативних індустрій крізь призму історичнокультурологічного аспекту визначається універсальністю та кроссекторальністю, забезпечуючи популяризацію і збереження культурних надбань нації.

Ключові слова: культура, історико-культурологічний аспект, проектний менеджмент, креативні індустрії, управління проектною діяльністю у креативних індустріях, проектна культура особистості, конкурентоспроможність.
\end{abstract}

In any science, in any art, experience is the best teacher. Miguel de Cervantes

Introduction. The cultural and creative environment is constantly changing in accordance with the challenges of time and the needs of society. Based on these positions and taking into account the results of scientific research in the historical and cultural aspect, we note that the activities of the creative sector require the activation of innovative, creative management methods, creative implementation of cultural products, which in practice is implemented through project management.

The urgency is due to the need to study the innovative paradigm of the cultural and creative sector, under the influence of which creative ideas are born and implemented. Currently, the search for creative ideas is taking place in all sectors of the creative industries. Cultural managers are looking for various innovative forms of bringing art and culture closer to the viewer, with the opportunity to develop and promote a cultural product. Effective project management should be considered as a strategic tool in this context. It is important to take into account the multifaceted implementation in the cultural and creative space. In particular, we are convinced that the conceptual foundations of project management in the creative industries are determined on the basis of cultural, creative, social, human-centered and economic aspects. At the same time, it should be noted that the organization of exhibitions, festivals, performances, open-air, cultural and tourist routes, successful implementation of cultural projects in creative industries require effective project management and effective project activities in retrospect. Uncertain parts of the general issues are the historical and cultural approach to the implementation of project management in the creative industries of the cultural space, through the prism of anthropocentrism. It is this approach that we bring to the research plane of the proposed article.

The analysis of the latest researches and publications gives the chance to generalize that dynamics of modern scientific researches is marked by a wide range of researched problems. Scientists identify the essence, principles, patterns, components and functional features of project management. In general, the issue attracts the attention of a large number of scientists who study the features of implementation, stages, interaction and main components in various fields.

In particular, the peculiarities of the project activity in their scientific research were considered M. Hurevych, L. Voropaieva, O. Kopernik, V. Symonenko, M. Romanovska, D. Khihni. A thorough study of project management as a process of managing the team and project resources using specific methods is presented D. Khihni (2018). The author emphasizes that due to the implementation of the methodological approach the project is completed successfully and achieves its goal (Khihni, 2018).

Theoretical and methodological foundations of project management in general have been studied by such researchers as: V. Cydorenko, K. Kantor, S. Krymskyi. In their scientific research, the authors reveal the problems of project culture and the mechanism of design. The methodology and mechanisms of project management in their 
scientific research are also disclosed Z. Drahan, J O'Connor, K. Kheldman. In particular, researcher and practitioner J. O'Connor emphasizes that the possession of creativity provides individuals with the opportunity to successfully cooperate in the process of professional activity, to carry out high-level communicative interaction in the process of project activities and to generate creative ideas (O'Connor, 2009). We are convinced that creativity in the process of implementing a cultural project in the creative industries provides uniqueness and innovation of both the personality of the cultural manager and project management in the creative industries in general.

They pay attention to the study of project management in the socio-cultural sphere S. Bezkubenko, O. Bezpalko, K. Hreia, P. Hurevych, S. Zuieva, T. Kalyta, V. Lukov, A. Markov, Ya. Martynyshyn, N. Noskova, N. Kohan, I. Petrova, V. Rizun, M. Shevchuk. We believe that the basis of the culturological approach to project management in the creative industries is formed by research S. Bezkubenko (2013). According to the author, one of the important features of culture is that it combines not only acquired historical material and spiritual values, but also the knowledge and skills of people living in a certain historical period, as a kind of creative potential that they realize in activities. Since the peculiarity of culture is the presence of constant exchange of knowledge of modern people with the possessions that were made by their ancestors, the importance of enriching the knowledge and skills of modern generations, mastering the experience of creative activity in the implementation of cultural and creative product (Bezkubenko, 2013). Given this, we can say about the importance of a creative approach in the implementation of project management in creative industries.

Project management in the creative industries has been the subject of research by researchers such as: S. Bushuiev, F. Visentini, V. Holtsmann, R. DeFilippi, A. Ivanova, L. Matstsini, P. Praseto, M. Ruseva, T. Sumynova, V. Tarnovskyi, H. Tulchynskyi ets. In their research, the authors emphasize that project management should be considered as a set of tasks, organization, methods and tools for project implementation. In particular, S. Bushuiev (2015), argues that the characteristics of the project can be defined as a set of management tasks and organizational actions, methods and tools aimed at achieving a specific goal of the project.

An interesting study in the context of the study is the development M. Ruseva (2019). The author singles out the key aspects of interaction of art organizations for the implementation of joint project proposals, namely: interdisciplinarity and expansion of interaction formats, as it is necessary to respond to new consumer preferences; the amount of resources, the involvement of partners to perform specific tasks for which artistic organizations lack their own resources or competencies; the need to expand and enhance competencies in project management and, in this regard, the implementation of marketing and management educational programs, development of algorithms and mechanisms for the implementation of certain tasks and projects (fundraising, volunteer work, etc.) (Ruseva, 2019). The effectiveness of this interaction depends on various factors that can have both positive and negative effects in the process of project interaction between art organizations in the creative industries.

In turn A. Ivanova (2017) project management considers directly through the prism of the functioning of regional cultural and creative industries. Namely, the author considers the cultural and creative industries as a highly innovative component with significant potential for capital formation, job creation through the creation and use of intellectual property. The development of cultural and creative industries and the creation of partner networks in this area is a modern and vital goal of the modern social and cultural space. Finding opportunities to realize creativity and create innovative business models that promote cultural projects is one of the most important prospects for regional development (Ivanova, 2017).

Summing up the analysis of scientific research, we consider it expedient to focus the research goal on theoretical and methodological understanding and substantiation of the peculiarities of project management implementation in creative industries, through the prism of historical and cultural aspect.

To achieve the goal of scientific research, the following tasks are identified:

- to reveal the theoretical and methodological principles of project management in the cultural and creative environment of creative industries;

- to analyze the historical and cultural aspect of project management in creative industries in Ukraine.

The methodological basis of the study is a set of research methods of general and special nature. In particular, methods of analysis and synthesis, dialectical, socio-cultural, historical-cultural and systemic approaches.

Main part. Note that any cultural and creative initiative begins with a creative idea and project. Let's focus in more detail on the features and specifics of understanding the "cultural project in the creative industries". In general, a cultural project can be considered as a relevant activity in the creative industries, aimed at creating a cultural product, cultural good or service. Revealing the main characteristics of the cultural project of creative industries, we highlight: clearly defined goals, budget, deadlines, plan and planning of the project.

After all, the cultural effect, expressed through the promotion of cultural diversity, preservation of cultural and national identity, satisfaction of people involved in cultural fields (Pick, 1986).

Implementation of effective management of cultural projects provides effective solution of selected tasks and implementation of creative ideas through the introduction of effective project management with copyright in projects. Because it is the diversity and synergy of creative industries that contributes to the development of Ukrainian society. Revealing the historical and cultural aspect of the features of project management in the creative industries, we note that the basis is values, ideas, interests, goals and means of achievement.

As stated on the official website of the Ukrainian Kul Fund, project management should be considered as initiating, planning, conducting, managing, controlling, networking, communication and concluding projects in accordance with quality standards (Hlosarii UKF, 2018). 
Note that the methodology of project management in creative industries involves the development, implementation and development of a cultural project as a complex system that reproduces and operates in a dynamic external and internal environment in accordance with the transformational changes of society. The process of project management in the creative industries should be formed on the basis of three main components, in particular: corporate culture, professionalism, organization of the project management process (Khyhny, 2018).

Revealing the historical and cultural aspect of the issue, we consider it appropriate to note that today there are leading associations of project management. In particular, the Institute of Project Management (RMI), on the basis of which a directory on project management was created (A Guide to the Project Management Body of Knowledge PMBOK Guide). International Project Management Association (International project management association IPMA), founded in 1965 in Vienna. At the same time, RMI includes representatives of more than 180 countries, IRMA - about 50 world national project management associations (A Guide to the Project Management Body of Knowledge - PMBOK Guide, 2021). An important development of IRMA is the formed competencies in project management (IPMA Competence Baseline - ICB).

Consider the situation in Ukraine. The Ukrainian Association for Project Management "UkrNET" plays an important role (Ukrainian Project Management Association "UPMA"). From 1988 to 1991 he was a member of the Soviet Association for Project Management SOVNET, and in 1991 he began as an independent association. The main mission of the association is to form a style of corporate culture and competence in project management of enterprises and businesses of Ukraine on the basis of project management, which ensures competitiveness (Ofitsiinyi sait Ukrainskoi asotsiatsii upravlinnia proektamy "UkrNET"). Since 1993 UkrNET has become a member of the International project management association. The Association's efforts are aimed at developing a culture of project management using modern systems of certification of competence, staff, teams and organizations, methods and information systems. Carrying out international certification of professional project managers, organizations, consultants and trainers (teachers) on the basis of the IPMA ${ }^{\circledR}$ system, providing consulting services, conducting training courses on project management, publishing books, standards, textbooks, etc. Since 1997, the association has a direct cooperation agreement with a professional structure in the field of project management - PMI American Institute of Project Management.

The Ukrainian Cultural Foundation, a state investor in cultural and creative industries, should play an important role in forming the conceptual foundations of project management of Ukraine's creative industries. This is a state institution established in 2017, on the basis of the relevant Law of Ukraine, to promote the development of national culture and art in the country, providing favorable conditions for the development of intellectual and spiritual potential of the individual and society, wide access of citizens to national cultural heritage. and dissemination of new meanings and common values in society, as well as contributes to the preservation of cultural heritage and the development of Ukrainian culture in the context of current world trends (Ofitsiinyi sait UKF, 2021). At the initiative and with the support of the Ukrainian Cultural Foundation, cultural diversity, promotion of the creation of a cultural and creative product and integration of Ukrainian culture into the world cultural space are implemented. Projects are supported by the Ukrainian Cultural Foundation on a competitive basis.

Thus, the analysis of scientific and practical literature makes it possible to identify appropriate steps in the process of project management of cultural projects in creative industries. In particular, identify project initiators - form the name of the project - justify the relevance and feasibility of the project - determine the purpose of the project form the strategic goals and objectives of the project - plan the relevant expected results - identify partners - set deadlines - identify project success criteria - project budget. Therefore, effective project management should be considered as the basis for the implementation of a cultural project.

Note that the project management guide states that project management should be understood as the application of knowledge, skills, tools and methods to project implementation to meet the requirements of the project (A Guide to the Project Management Body of Knowledge - PMBOK Guide, 2021). Project management is carried out through the proper application and integration of logically grouped 47 project management processes, grouped into five groups: initiation (decision to start the project); planning (definition of the purposes and criteria of success of the project and development of working schemes of their achievement); implementation (coordination of people and other resources to implement the plan); monitoring and control (determination of compliance of the plan and project implementation with the set goals and success criteria and decision-making on the need to apply corrective actions, determination of necessary corrective actions, their coordination, approval and application); completion (formalization of the project and bringing it to an orderly final) (A Guide to the Project Management Body of Knowledge - PMBOK Guide, 2021). In general, a cultural project can be considered complete if the defined objectives and goals in the developed project management strategy are achieved.

The main task of project management is to achieve all the goals and objectives of the project, while fulfilling the obligations of the predetermined constraints of the project. Typical restrictions are the boundaries and content of the project, time, budget. A secondary but more ambitious task is to optimize, allocate and integrate the tasks needed to achieve predefined goals (Bohdanov, 2012). Appropriate resources are needed to implement a cultural project in the creative industries. These include intellectual (competence of the team to implement a cultural project), material (necessary tools, materials, technical means), financial (funds needed to implement a cultural project), management (project manager and team, management competence, culture of project activities), organizational (performance of tasks according to deadlines) (Drahan, 2013; Project Management Institute, 2019; Vasina, 2020). 
The analysis of scientific and practical sources makes it possible to single out a system of effective management of cultural projects in the environment of creative industries can be formed into an appropriate algorithm. In particular: management system: goals of the enterprise, organizations of creative industries ${ }^{\circledR}$

- project management in the environment of creative industries through the prism of the historical and cultural aspect is determined by the universality and cross-sectorality, ensures the promotion and preservation of cultural heritage of the nation;

- theoretical and methodological foundations of project management in the creative industries are a holistic concept of interconnected mechanisms, aspects, components, resources, methods and tools of effective management, through the prism of human-centeredness. All this is the basis of the roadmap for the successful implementation of cultural projects among the creative industries of Ukraine.

We are convinced that cross-sectoral collaboration, interdisciplinary cooperation in the process of project management will give a positive result in the development of creative industries and the cultural space of Ukraine in general.

\section{Bibliography:}

1. Безклубенко С.Д. Про поняття культура та культуру визначення понять. Культура і мистецтвво у сучасному світі. 2013. Вип. 14. С. 6-13.

2. Богданов В.В. Управление проектами. Корпоративная система - шаг за шагом. Москва : Манн, Иванов и Фербер, 2012. $248 \mathrm{c}$.

3. Бушуев С.Д., Бушуева Н.С., Бабаев И.А. Креативные технологии управления проектами и программами. Киев : Саммит-Книга, 2015. 768 c.

4. Воропаева Л.Н., Юрьева Т.В. Проектный менеджмент и основные методы его реализации. УЭКС. 2017. Order № 6 (100). URL: https://cyberleninka.ru/article/n/proektnyy-menedzhment-i-osnovnye-metody-ego-realizatsii.

5. Глосарій - поняття сталого культурного розвитку. 2018. URL: https://uccs.org.ua/uncategorized/hlosarij-poniattiastaloho-kulturnoho-rozvytku/.

6. Грантовий менеджмент від УКФ. Офіційний сайт Украйнський культурний фонд. URL: https://ucf.in.ua/p/management_lectures.

7. Драган 3.М. Набор инструментов для управления проектами. Москва : Академия АйТи, ДМК пресс. URL: http://pmwebinars.ru/wp-content/uploads/2013/07/Nabor-instrumentov-dlya-upravleniya-proektami.pdf.

8. Закон України «Про авторське право і суміжні права» від 23 грудня 1993 р. № 3792-XII. URL: https://zakon.rada.gov.ua/laws/show/3792-12.

9. Кові С.Р. 7 звичок надзвичайно ефективних людей. Харків : «Клуб Сімейного Дозвілля», 2014. 384 с.

10. Мартинишин Я.М., Костюченко О.В. Проектний менеджмент як стратегічний інструмент розвитку соціокультурної сфери. Вісник Національної академії керівних кадрів культури і мистеитв, 2018. № 4. С. 8-89.

11. Моргенстерн Дж. Технологии эффективной работы. Москва : Добрая книга, 2006. 336 с.

12. Носкова Н.А. Анализ практик проектного менеджмента в сфере культуры. Петербургский экономический журнал. № 4. URL: https://cyberleninka.ru/article/n/analiz-praktik-proektnogo-menedzhmenta-v-sfere-kultury.

13. Офіційний сайт Український культурний фонд. URL: https://uaculture.org/texts/kulturni-ta-kreatyvni-industriyizapidtrymkyukf-u-2018-roczi.

14. Офіційний сайт Української асоціації управління проектами «УкрHET». URL: http://upma.kiev.ua.

15. Петрова І.В. Проектування в соціально-культурній сфері : навчальний посібник. Київ : Вид-во КНУКіМ. 2007.

16. Плецан Х.В. Стан та тенденції розвитку формування конкурентоздатного фахівця в умовах пошуку нової парадигми в сфері туризму. Економіка і держава. 2018. № 6. С. 74-79.

17. Хелдман К. Профессиональное управление проектами. Москва : «Бином», 2005. 517 с.

18. Хигни Д. Основы проектного менеджмента: Классическое руководство. «Манн, Иванов и Фербер». 2018. 240 с.

19. Цивільний кодекс України від 16 січня 2003 р. № 435-IV. URL: https://ips.ligazakon.net/document/T030435.

20. Шевчук М.О., Доліна І.В. Проектна культура керівника: сутність поняття. Наукові записки. Серія «Психолого-педагогічні науки». 2017. № 3 URL: http://lib.ndu.edu.ua/dspace/handle/123456789/1018.

21. A Guide to the Project Management Body of Knowledge - PMBOK Guide. 2021. URL: https://www.pmi.org/pmbokguide-standards/foundational/PMBOK

22. DeFillippi R. Managing project-based organization in creative industries. The Oxford Handbook of Creative Industries. 2015. $268 \mathrm{p}$.

23. DeMarco T., Lister T. Peopleware: productive projects and teams. Addison-Wesley. 272 p. URL: https://books.google.com. ua/books/about/Peopleware.html?id=TVQUAAAAQBAJ\&redir_esc=y.

24. Holzmann V., Mazzini, L. Applying Project Management to Creative Industries: The Relationship Between Leadership Style and Project Success. Journal of Organizational Culture, Communications and Conflict. 2020. № 24 (1). P. 1-17.

25. Ivanova A. Framework for project management in the field of art and science. Proceedings of the scientific conference "Science, education and innovation in the field of art". Academy of Music, Dance and Fine Arts. 2017.

26. Kalyta T.V., Zariazhko T.V. Застосування проектної діяльності у сфері культури. Культура Украӥни. 2019. № 64. URL: https://doi.org/10.31516/2410-5325.064.13.

27. O'Connor J. Creative Industries: A new direction? International journal of cultural policy. Vol. 15. 4. 2009. P. 387-404.

28. Pick J. Managing the Arts? The British Experience. Rhinegold, London. 1986.

29. Prasetyo P. Eko; Dzaki Fuad Zainul. Efficiency performance and productivity of creative industries. International Journal of Advanced Science and Technology. 2020. № 9.6. P. 122-132.

30. Project Management Institute. The Standard for Risk Management in Portfolios, Programs, and Projects. 2019. 341 p. 
31. Ruseva M. Project Management In The Creative Industries. CBU International Conference Proceedings. P. $269-277$. https://doi.org/10.12955/cbup.v7.1372.

32. Vasina A. et al. Implementation of Digital Technologies into Projects in Area of Creative Industries. EcologicalSocio-Economic Systems: Models of Competition and Cooperation (ESES 2019). Atlantis Press, 2020. P. 26-32.

33. Vicentini F., Nasta L. Team and time within project-based organizations: Insights from creative industries. Learning and innovation in hybrid organizations. Palgrave Macmillan, Cham. 2018. P. 33-49.

34. Wysocki R.K., McGary R. Effective Project Management, Wiley Publishing, Inc. Third edition, 2018. 504 p.

\section{References:}

1. Bezklubenko, S.D. (2013). Pro poniattia kultura ta kulturu vyznachennia poniat. [About the concept of culture and the culture of defining concepts]. Kultura i mystetstvo u suchasnomu sviti. Vyp. 14. 6-13 [in Ukrainian].

2. Bohdanov, V.V. (2012). Upravlenye proektamy. Korporatyvnaia systema - shah za shahom. [Project management. Corporate system - step by step]. Moskva : Mann, Yvanov y Ferber, 248 [in Russian].

3. Bushuev, S.D, Bushueva N.S., Babaev Y.A. (2015). Kreatyvnye tekhnolohyy upravlenyia proektamy y prohrammamy. [Creative technologies for project and program management]. Kyev: Sammyt-Knyha, 768 [in Russian].

4. Voropaeva, L.N., Yureva T.V. (2017). Proektnyi menedzhment y osnovnye metody eho realyzatsyy. [Project management and basic methods of its implementation]. UEkS. Order № 6 (100). URL: https://cyberleninka.ru/article/n/proektnyymenedzhment-i-osnovnye-metody-ego-realizatsii. [in Russian].

5. Hlosarii - poniattia staloho kulturnoho rozvytku, (2018). [Glossary - the concept of sustainable cultural development]. Retrieved from https://uccs.org.ua/uncategorized/hlosarij-poniattia-staloho-kulturnoho-rozvytku [in Ukrainian].

6. Hrantovyi menedzhment vid UKF, (2020). [Grant management from UKF]. Ofitsiinyi sait Ukrainskyi kulturnyi fond. Retrieved from https://ucf.in.ua/p/management lectures. [in Ukrainian].

7. Drahan, Z.M. (2013). Nabor ynstrumentov dlia upravlenyia proektamy. [Project Management Toolkit]. Moskva: Akademyia AiTy, DMK press. Retrieved from http://pmwebinars.ru/wp-content/uploads/2013/07/Nabor-instrumentovdlya-upravleniya-proektami.pdf. [in Russian].

8. Zakon Ukrainy "Pro avtorske pravo i sumizhni prava" vid 23.12.1993 № 3792-XII. Retrieved from https://zakon.rada.gov. ua/laws/show/3792-12 [in Ukrainian].

9. Kovi, S.R. (2014). 7 zvychok nadzvychaino efektyvnykh liudei. [7 habits of extremely effective people]. Kharkiv : Klub Simeinoho Dozvillia, 384 [in Ukrainian].

10. Martynyshyn Ya.M., Kostiuchenko O.V. (2018). Proektnyi menedzhment yak stratehichnyi instrument rozvytku sotsiokulturnoi sfery. [Project management as a strategic tool for the development of the socio-cultural sphere]. Visnyk Natsionalnoi akademii kerivnykh kadriv kultury i mystetstv, (4), 84-89 [in Ukrainian].

11. Morgenstern, Dzh. (2006). Tehnologii effektivno. [Efficient work technologies]. Moskva : Dobraya kniga, 336 [in Russian].

12. Noskova, N.A. (2018). Analiz praktik proektnogo menedzhmenta $\mathrm{v}$ sfere kulturyi. [Analysis of project management practices in the field of culture]. Peterburgskiy ekonomicheskiy zhurnal. № 4. Retrieved from https://cyberleninka.ru/ article/n/analiz-praktik-proektnogo-menedzhmenta-v-sfere-kultury. [in Russian].

13. Ofitsiinyi sait Ukrainskyi kulturnyi fond. Retrieved from https://uaculture.org/texts/kulturni-ta-kreatyvni-industriyizapidtrymkyukf-u-2018-roczi [in Ukrainian].

14. Ofitsiinyi sait Ukrainskoi asotsiatsii upravlinnia proektamy «UkrNET». Retrieved from http://upma.kiev.ua. [in Ukrainian].

15. Petrova, I.V. (2007). Proektuvannia v sotsialno-kulturnii sferi: navch. posib. [Design in the socio-cultural sphere: textbook. way]. Kyiv: Vyd-vo KNUKiM. [in Ukrainian].

16. Pletsan, Kh.V. (2018). Stan ta tendentsii rozvytku formuvannia konkurentozdatnoho fakhivtsia v umovakh poshuku novoi paradyhmy v sferi turyzmu. [Status and development trends of the formation of a competitive specialist in terms of finding a new paradigm in the field of tourism.]. Ekonomika i derzhava. № 6. S. 74-79 [in Ukrainian].

17. Kheldman, K. (2005). Professyonalnoe upravlenye proektamy. [Professional project management]. Moskva: Bynom. 517 [in Russian].

18. Higni, D. (2018). Osnovyi proektnogo menedzhmenta: Klassicheskoe rukovodstvo. [Fundamentals of Project Management: Classical Leadership]. "Mann, Ivanov i Ferber”. 240 [in Russian].

19. Tsyvilnyi kodeks Ukrainy vid 16.01.2003 № 435-IV. Retrieved from https://ips.ligazakon.net/document/T030435/ [in Ukrainian].

20. Shevchuk, M.O., Dolina, I.V. (2017). Proektna kultura kerivnyka: sutnist poniattia. [Project culture of the head: the essence of the concept]. Naukovi zapysky. Seriia “Psykholoho-pedahohichni nauky”. № 3. Retrieved from http://lib.ndu.edu.ua/ dspace/handle/123456789/1018 [in Ukrainian].

21. A Guide to the Project Management Body of Knowledge - PMBOK Guide. (2021). Retrieved from https://www.pmi.org/ pmbok-guide-standards/foundational/PMBOK [in English].

22. DeFillippi, R. (2015). Managing project-based organization in creative industries. The Oxford Handbook of Creative Industries., 268. [in English].

23. DeMarco, T., \& Lister, T. (2013). Peopleware: productive projects and teams. Addison-Wesley. 272 . Retrieved from https://books.google.com.ua/books/about/Peopleware.html?id=TVQUAAAAQBAJ\&redir_esc=y [in English].

24. Holzmann, V., \& Mazzini, L. (2020). Applying Project Management to Creative Industries: The Relationship Between Leadership Style and Project Success. Journal of Organizational Culture, Communications and Conflict, 24(1), 1-17. [in English].

25. Ivanova, A. (2017). Framework for project management in the field of art and science. Proceedings of the scientific conference "Science, education and innovation in the field of art". Academy of Music, Dance and Fine Arts. [in English]. 
26. Kalyta, T.V., \& Zariazhko, T.V. (2019). Zastosuvannia proektnoi diialnosti u sferi kultury. [Application of project activities in the field of culture]. Kultura Ukrainy, (64). Retrieved from https://doi.org/10.31516/2410-5325.064.13 [in Ukrainian].

27. O’Connor, J. (2009). Creative Industries: A new direction? International journal of cultural policy. Vol. 15.4. P. 387-404 [in English].

28. Pick, J. (1986), Managing the Arts? The British Experience, Rhinegold, London. [in English].

29. Prasetyo, P. Eko; Dzaki, Fuad Zainul (2020). Efficiency performance and productivity of creative industries. International Journal of Advanced Science and Technology, 9.6: 122-132. [in English].

30. Project Management Institute (2019). The Standard for Risk Management in Portfolios, Programs, and Projects. 341 p. [in English].

31. Ruseva, M. (2019). Project Management In The Creative Industries. In: CBU International Conference Proceedings. p. 269-277. Retrieved from https://doi.org/10.12955/cbup.v7.1372 [in English].

32. Vasina, A. et al. (2020). Implementation of Digital Technologies into Projects in Area of Creative Industries. In: EcologicalSocio-Economic Systems: Models of Competition and Cooperation (ESES 2019). Atlantis Press, 26-32. [in English].

33. Vicentini, F., \& Nasta, L. (2018). Team and time within project-based organizations: Insights from creative industries. In Learning and innovation in hybrid organizations (pp. 33-49). Palgrave Macmillan, Cham. [in English].

34. Wysocki R.K., McGary R. (2018). Effective Project Management, Wiley Publishing, Inc. Third edition, 504 p. [in English]. 